the existence of American principle. (The gap was sufficiently significant, indeed, to keep Whitman from making any serious effort to get to the polls.) Whitman may have hoped, in "Election Day," for another Jefferson or Lincoln, but he failed to take the first step in promoting one-namely, distinguishing for the public (in his most public and cherished forum, poetry) authentic Jeffersonianism or Lincolnism from poor substitutes. By the 1880 s he had lost the enthusiasm that twenty years earlier had inspired him to make-clearly and with passion-those very kinds of distinctions.

The University of Iowa

Nicholas Natanson

\title{
NOTES
}

1 See Alan Trachtenberg, The Incorporation of America: Culture and Society in the Gilded Age (New York: Hill and Wang, 1982), especially pp. 70-100.

2 Allan Nevins, Grover Cleveland: A Study in Courage (New York: Dodd, Mead, and Co., 1933), 177-178.

3 Horace Traubel, With Walt Whitman in Camden (1905, rpt. New York: Rowman and Littlefield, 1961), 1:341.

4 Traubel, 1:373, 386.

5 Floyd Stovall, ed., Prose Works 1892 (New York: New York University Press, 1964), 2:399.

6 Traubel, 1:386.

7 See Edward Grier, ed., Notebooks and Unpublished Prose Manuscripts (New York: New York University Press, 1984), 4:1204; Traubel, 1:147.

8 See Edwin Haviland Miller, ed., The Correspondence (New York: New York University Press, 1964), 3:348n.

9 Grier, 4:1204.

10 Grier, 4:1204.

11 Harold W. Blodgett and Sculley Bradley, eds., Leaves of Grass, Comprehensive Reader's Edition (New York: New York University Press, 1965), 517. All quotations from Leaves are from this edition.

\section{WHITMAN'S “OVERSTAID FRACTION": SECTION 38 OF "SONG OF MYSELF"}

Although not so well-known as "that two-handed engine at the door" in "Lycidas," it nevertheless remains a crux of some importance: what does Whitman mean in Section 38 of "Song of Myself" when he says enigmatically, "I resume the overstaid fraction"?

The question is significant, since it concerns a central passage in the poem, one that begins in collapse and ends in restoration and recovery. ${ }^{2}$ The poet has been overcome by feelings of weakness, worthlessness, and error. "Enough! enough! enough!" he cries out: 
Somehow I have been stunn'd. Stand back!

Give me a little time beyond my cuff'd head, slumbers, dreams, gaping,

I discover myself on the verge of a usual mistake.

From this moment of helplessness he moves, in seven lines, to splendid recovery. "I troop forth replenished with supreme power," he proclaims; and the poem then proceeds to confident, even ecstatic, celebration. How does it happen? Look at the transitional lines:

That I could forget the mockers and insults!

That I could forget the trickling tears and the blows of the bludgeons and hammers!

That I could look with a separate look on my own crucifixion and bloody crowning!

I remember now,

I resume the overstaid fraction,

The grave of rock multiplies what has been confided to it; or to any graves,

Corpses rise, gashes heal, fastenings roll from me.

Any interpretation of Section 38 of "Song of Myself" must concern itself with three questions: What is the "usual mistake" that the poet discovers? What does it mean to look "with a separate look"? And what is the "overstaid fraction" that is resumed?

Clearly, we are dealing with a crisis of some sort. The poet, stunned and silent, is in danger. What could have caused such a collapse? The poem began with joyous confidence, but where now is the poet who greeted us by saying, "I celebrate myself and sing myself"? By way of answer, note that for about 150 lines the passages leading up to this breakdown have described loss and suffering: the wife screaming at the sight of her husband's drowned corpse, the rescue at sea, the runaway slave, "the mash'd fireman with breast-bone broken," the fury of war, the general dying in combat, the slaughter of 412 young men at Goliad, the "old-time sea fight" with its chilling conclusion after the battle:

The hiss of the surgeon's knife, the gnawing teeth of his saw,

Wheeze, cluck, swash of falling blood, short wild scream, and long, dull, tapering groan,

These so, these irretrievable.

This sequence of grim passages leads up to Section 37, in which the poet, through his powers of sympathetic imagination, so closely identifies with the sufferers he depicts that he becomes one of them:

You laggards there on guard! look to your arms!

In at the conquer'd door they crowd! I am possess'd!

Embody all presences outlaw'd or suffering,

See myself in prison shaped like another man,

And feel the dull unintermitted pain. 
The 1855 text is even stronger: it begins, "O Christ! My fit is mastering me!" The poet is overcome - "possess'd" - by forces beyond his control, so that by the end of Section 37, as various critics have noted, he is reduced to Job-like ignominy and impotence. ${ }^{3}$ "I project my hat," he laments, "sit shame-faced, and beg" (958). He is imprisoned in darkness, without a hint of his former buoyancy; from such a state, what redemption is possible?

However it may be achieved, redemption begins with the discovery of a "usual mistake." The conscious mind at least recognizes the danger it is in, for it has not lost its powers of articulation. Somehow it can exert itself against the imagination, in a reversal of the usual Romantic emphasis, and move toward a way out. It finds itself making the "usual mistake." And what is that?

This mistake has been identified in various ways. One critic has observed that it is the poet's "momentary withdrawal from the relation of empathy which he has established with mankind." Another, agreeing substantially with this reading, has written: "The 'mistake' is one of separation emotional distance and failure of sympathy." ${ }^{\prime 4}$ As I have suggested, however, the text indicates not separation from other people, but rather a sympathetic union with them, especially with those who suffer. The union is so complete that the poet's own identity becomes lost in the identities of others: "Askers embody themselves in me and I am embodied in them" (957).

Taking a different approach, James E. Miller, J Jr. has written that the "usual mistake" is "the exclusion of the Divine, the Infinite." But such exclusion, as Sholom Kahn has pointed out, is better seen as a result of the mistake, rather than the mistake itself. Another interpretation, psychoanalytic in orientation, asserts that the "usual mistake" is "to engage in the process of identification ... in an effort to escape mortality." The text will not support such a reading, however, since it seems unlikely that such an effort would be "usual"; furthermore, after the poet has recognized his mistake, he defiantly asserts that he has escaped mortality, just as he did at earlier points in the poem. Compare, for example, line 406 - "I know that I am deathless"with line 1080: "I acknowledge the duplicates of myself, the weakest and shallowest is deathless with me."

What, then, is the "usual mistake"? I would suggest that it is primarily a failure of the poetic imagination. In Section 4 of "Song of Myself" Whitman describes his position as being "Both in and out of the game and watching and wondering at it." As a poet he could be participant and observer: while living among people he could retain the detachment necessary to step back as an artist observing human events even while participating in them-with the aesthetic distance necessary for his art. To be "both in and out of the game" is to separate the poet from the man; Whitman thus anticipates T. S. Eliot's assertion in "Tradition and the Individual Talent" that "the more perfect the artist, the more completely separate in him will be the man who suffers and the mind which creates." 8 Curiously, Whitman has commented that he felt as though he were two people: "I cannot understand the mystery," he wrote in one of his notebooks, "but I am always conscious of myself as two (my soul and I)."

The collapse of the poet in Section 38 comes about precisely because the man and the poet abandon their separateness and become one as the poet falls victim to the man's sympathetic imagination. "I am possess'd," he cries out (946), overcome by the feelings that have seized him. It is possible, Whitman suggests - now anticipating D. H. Lawrence's criticism of him - to feel too much sympathy, to identify too completely with the lives of others and thereby lose not only the aesthetic detachment 
necessary for artistic creation, but also, in a larger sense, to abandon one's identity. Thus the "usual mistake": succumbing to an imagination that loses control of itself through excessive sympathy, overwhelmed by emotion. ${ }^{10}$ The result is always the same, a confusion of identities that invariably diminishes one's sense of self, as the poet becomes a beggar when he could be-should be-like a god.

The recovery begins with recognition:

That I could forget the mockers and insults!

That I could forget the trickling tears and the blows of the bludgeons and hammers!

That I could look with a separate look on my own crucifixion and bloody crowning.

What did he forget? The lines obviously allude to Christ's crucifixion, but in what way and for what purpose? The poet imagines himself in the place of Christ, but there's a fault, as suggested by the phrase, "with a separate look." This "separate look" is wrong because it is too exclusive: a partial view, incomplete and limited. The crucifixion scene described here is one of pain and torment, but that is not the end of it. More important, the crucifixion is a means to resurrection. To see it separately is to confine it to the painful present, forgetting the triumphant future.

It is this triumph that the poet recalls in the lines immediately following the crucifixion passage:

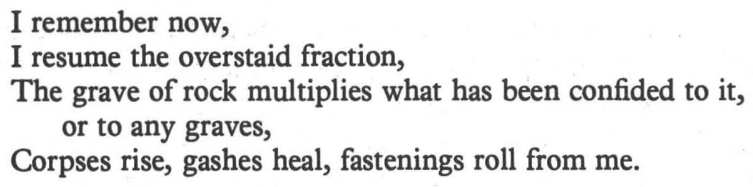

(966-969)

Here we have images of rebirth and renewal, and they lead right to the poet's recovery in the next line: "I troop forth replenish'd with supreme power." Memory has saved him; even this crisis cannot extinguish what the poet has known, although it may for a time obscure essential knowledge. The poet has within himself the means to his own salvation ("Nothing can bring you peace but yourself," wrote Emerson in "Self-Reliance"). From this moment of discovery the poem moves outward toward celebration. One may think of a similar turn, also dependent on memory, in Wordsworth's "Ode: Intimations of Immortality":

\section{$\mathrm{O}$ joy! that in our embers \\ Is something that doth live, That nature yet remembers What was so fugitive!}

What then is the "overstaid fraction" that the poet resumes? To "overstay" is "to stay beyond the time or duration of; outstay." A "fraction" is "a part as distinct from the whole of anything; a portion or section." 11 The poet takes up that part of himself which he has too long put aside; he moves from the human perspective to the sacramental. He has forgotten the unity of things in his absorption with the merely human; memory tells him that suffering is not the end, that a proper perspective would find cause for celebration rather than grief. ${ }^{12}$ His mistaken view was partial 
("separate"); to see the whole pattern is to find cause for rejoicing. Near the end of the poem he says it plainly: "Do you see $\mathrm{O}$ my brothers and sisters? / It is not chaos or death-it is form, union, plan-it is eternal life-it is Happiness" (1017-1018).

At the moment of crisis the poet is fragmented, a mere part of himself; when he recovers, he achieves the integration, the wholeness of being so eagerly sought by Emerson and other Romantics. He regains the detachment that allows him to know the sorrows of human life without becoming overwhelmed by them. He achieves the god-like perspective that sees the creation as good, and he knows that his work is to celebrate and sing. He becomes, in short, the central man, the poet.

Significantly, the section immediately following the recovery presents "The friendly and flowing savage," a man who has never lost the wholeness that was his at birth:

Behavior lawless as snow-flakes, words simple as grass, uncomb'd head, laughter, and naivetè,

Slow-stepping feet, common features, common modes and emanations,

They descend in new forms from the tips of his fingers,

They are wafted with the odor of his body or breath, they fly out of the glance of his eyes.

(983-986)

Such a natural man knows nothing of tragedy. For him, everything is in its place; there is nothing to mourn. He is at peace with himself and this world. As if strengthened by the presence of this man, the poet moves ahead with confidence. Jauntily he addresses the earth and the sun:

Flaunt of the sunshine I need not your bask-lie over!

You light surfaces, I force surfaces and depths also.

Earth! you seem to look for something at my hands,

Say, old top-knot, what do you want?

(987-990)

Far from being powerless, he now offers aid to others: "I am he bringing help for the sick as they pant on their backs, / And for strong upright men I bring yet more needed help" (1020-1021). He celebrates his very being, all shame and fear cast aside; "I am an acme of things accomplish'd," he proclaims, "and I am encloser of things to be" (1148). And so, with the assurance of a god, the poet joyfully proceeds to the end of his poem, fully restored, in effortless control of himself, the crisis passed.

University of Massachusetts

R. W. FRENCH

\section{NOTES}

1 All quotations of "Song of Myself" are from Leaves of Grass, ed. Sculley Bradley and Harold W. Blodgett (New York: W. W. Norton and Company, 1973).

2 The importance of Section 38 needs to be emphasized. Sholom J. Kahn is surely right when he refers to this section as the "central, most critical, conflict of the poem," adding that this crisis is approached through Sections 30-37, "where the soaring ' $\mathrm{I}$ ' achieves a maximum of Identification . . . with vast ranges of human experience, chiefly of heroism and suffering" 
("Whitman's 'Overstaid Fraction' Again," Walt Whitman Review 20 [June 1974], 67). The crisis of Section 38, it should be noted, is a crisis of the mind; it thus parallels the earlier major crisis in the poem, which is of the body: the "Touch" crisis of Sections 27-29 (lines 611-647), in which the poet also loses control of himself, although for obviously different reasons.

3 See, for example, James E. Miller, Jr., A Critical Guide to Leaves of Grass (Chicago: University of Chicago Press, 1957), 24: "Here [at the end of Section 37] the poet reaches the nadir of degradation, particularly in the emotion of shame."

4 Joel Jay Belsen, “Whitman's 'Overstaid Fraction," Walt Whitman Review 17 (June 1971), 64; Kahn, 71.

5 James E. Miller, Jr., A Critical Guide, 25.

6 Kahn, 71.

7 Stephen A. Black, Whitman's fourneys into Chaos: A Psychoanalytic Study of the Poetic Process (Princeton: Princeton University Press, 1975), 96.

8 Selected Essays (New York: Harcourt, Brace \& World, Inc., 1960), 7-8.

9 Notebooks and Unpublished Prose Manuscripts, ed. Edward F. Grier (New York: New York University Press, 1984), 1:63. For a shrewdly perceptive contemporary treatment of the dual nature of the artist, see Jorge Luis Borges, "Borges and I," in Labyrinths: Selected Stories and Other Writings (New York: New Directions, 1964), 246-247.

10 In a helpful and perceptive reading of "Song of Myself," Howard J. Waskow has written, "The 'usual mistake' is to stay too long in the poetic night - to assume that the self is so healthy and whole that it can exchange identities endlessly, without injuring itself or the process." (Whitman: Explorations in Form [Chicago and London: The University of Chicago Press, 1966], 180.)

11 This is the clear and obvious meaning. Joel Jay Belsen's definition (Belsen, 65) of "fraction" as "the rite of breaking the bread in the celebration of the Eucharist" is far too strained a reading to merit consideration. As Sholom J. Kahn comments (73), "To wrench the 'fraction' out of context and import the Eucharist here is not to read Whitman, but to write one's own poem. ... The test of a proper critical reading must be the poetic text as a whole."

12 Edwin Haviland Miller's comment on this passage is particularly helpful: "When he [the poet] resumes the 'overstaid fraction' he is ready to 'troop forth replenished with supreme power, one of an average unending procession': he has been preoccupied with pain, which excludes or minimizes joy; he has been preoccupied with defeat, which excludes victory; tragedy, or 'my own crucifixion,' has absorbed him in the separateness of pain and self-pity and has momentarily eclipsed the comic vision of men united in joy" (Walt Whitman's Poetry: A Psychological fourney [New York: New York University Press, 1968], 106).

\section{WHITMAN AND VAN GOGH: AN EXCHANGE}

In her essay "Van Gogh's 'Starry Night' and Whitman: A Study in Source" (WWQR, 3 [Summer 1985], 1-15), Jean Schwind stresses the influence that Whitman's poetry, especially From Noon to Starry Night, must have had on the creation of Van Gogh's "Starry Night" of June 1889. In the second half of the article Schwind points to the painting "Wheatfield with Cypress" (National Gallery, London [F 615]), which she calls its "daylight counterpart." From this juxtaposition she develops a comparison between these two paintings and Whitman's poems "Prayer of Colum- 